\title{
Comparing the effects of community service and short-term imprisonment on recidivism: a matched samples approach
}

\author{
Hilde Wermink • Arjan Blokland • \\ Paul Nieuwbeerta • Daniel Nagin • Nikolaj Tollenaar
}

Published online: 19 June 2010

(C) The Author(s) 2010. This article is published with open access at Springerlink.com

\begin{abstract}
This study uses longitudinal official record data on adult offenders in The Netherlands $(n=4,246)$ to compare recidivism after community service to that after short-term imprisonment. To account for possible bias due to selection of offenders into these types of sanctions, we control for a large set of confounding variables using a combined method of 'matching by variable' and 'propensity score matching'. Our findings demonstrate that offenders recidivate significantly less after having performed community service compared to after having been imprisoned. This finding holds for both the short- and long-term. Furthermore, using the Rosenbaum bounds method, we show that the results are robust for hidden bias.
\end{abstract}

Keywords Community service $\cdot$ Imprisonment $\cdot$ Quasi-experiment $\cdot$ Propensity scores $\cdot$ Recidivism $\cdot$ Incarceration

\section{Introduction}

Ever since its introduction in the Dutch Criminal Code in 1989, community service has been an increasingly important sentencing option in The Netherlands. Community service is a distinct sentencing option for adult offenders and is non-

H. Wermink $(\bowtie) \cdot$ P. Nieuwbeerta

Department of Criminology, Leiden University, P.O. Box 9520, 2300 RA Leiden, The Netherlands e-mail: h.t.wermink@law.leidenuniv.nl

\section{A. Blokland}

Netherlands Institute for the Study of Crime and Law Enforcement (NSCR), Amsterdam, The Netherlands

\section{Nagin}

Carnegie Mellon University, Pittsburgh, PA, USA

\section{N. Tollenaar}

Research and Documentation Centre, Ministry of Justice (WODC), The Hague, The Netherlands 
profit or tax-supported agencies to serve a specified number of hours performing work or service within a given time limit as a sentencing option or condition" (Harris 1979: 6). In the Dutch criminal justice system, community service must benefit the community and can be performed in the offender's spare time (Tak 2001). At its introduction, community service was intended to ease the pressure on the prison system, to reduce recidivism rates, and to be a more humane sanction compared to imprisonment. Furthermore, community service was aimed to cut the costs of the Dutch prison system (Kamerstukken II 1986-1987, 20 074, nr. 6, p. 2-3). Other European countries as well as the U.S. also use community service as an alternative to short-term imprisonment (Tonry and Frase 2001).

As of 1989, criminal courts in The Netherlands may impose community service of maximally 240 hours only to replace an unconditional imprisonment of six months or less, or a partly suspended imprisonment of which the unconditional part would be six months or less. From 2001 onwards, community service can also serve as a primary penalty instead of exclusively to replace short-term imprisonment. In The Netherlands, the number of offenders sentenced to community service increased substantially from 14,485 in 1997 to 32,590 in 2007 (Statistics Netherlands 2008). An increasing trend in the use of community service is also noticeable in other countries (Tonry and Frase 2001).

The introduction and subsequent increase in the use of community service leads to an important question which we will try to answer in this paper: to what extent is community service a good alternative for short-term imprisonment, especially concerning recidivism rates after these punishments?

A recent Dutch study shows that more than $60 \%$ of offenders recidivate after serving imprisonment compared to $40 \%$ of those sentenced to community service (Wartna 2009). However, this difference does not necessarily result from a causal effect of the type of sentence, it can also (partly) be explained by selection processes taking place when offenders are sentenced to either community service or imprisonment. Compared to those sentenced to imprisonment, individuals sentenced to community services are more likely to be first offenders and to have committed less serious crimes (Tonry and Frase 2001). Such selection processes make the imprisoned group disproportionately crime prone beforehand, regardless of any potential causal effect of the different sanctions. Consequently, existing differences between offenders must be carefully accounted for when comparing recidivism after community service to that after imprisonment.

To date, only four studies have compared recidivism rates after community service and after imprisonment using an adequate quasi-experimental design ${ }^{1}$ (Bol and Overwater 1986; Muiluvuori 2001; Nirel et al. 1997; Spaans 1994) and only two experimental studies, using the same dataset, were conducted (Killias et al. 2000;

\footnotetext{
1 These are studies conducted at least at the fourth level of the Scientific Methods Scale (see Sherman et al. 1997). In short, the Maryland Scientific Methods Scale is a simple five-point scale of methodological quality. It is argued that objective conclusions can only be drawn when studies are conducted on at least the fourth level. Quasi-experimental studies compare an experimental group and a control group. Individuals are not randomly assigned to these groups. However, these studies statistically control for confounding variables or the studies show clearly that the groups are comparable on these confounding variables. In studies with an experimental design at least one internal variable is manipulated, i.e. the assignment of offenders to either community service or imprisonment.
} 
Gilliéron et al. 2006). The most important limitation of the quasi-experimental studies is that selection processes are not sufficiently accounted for. While appropriately controlling for selection effects, the small sample and its regional character compromise the generalizability of the experimental results. The current study therefore aims to extend prior research in multiple ways. Based on official data on all offenders sentenced to either community service or short-term imprisonment in The Netherlands in 1997, we compare post-sentence recidivism for a period of up to eight years. Using both matching by variable and propensity score matching, we control for many possible confounding variables. Rosenbaum bounds are applied to test for the robustness of our findings to unobserved sources of selection bias.

\section{Community service and imprisonment in criminological perspective}

The central question in this study is to what extent community service is either more or less effective than imprisonment in mitigating recidivism. A theoretical answer to this question can be derived from several criminological theories that lead to contradicting hypotheses.

On the one hand, based on deterrence theory it can be expected that community service results in higher recidivism than imprisonment. Within the deterrence framework the major aim of official interventions is to discourage offenders from committing future crimes. Specific deterrence occurs when those who have been punished cease offending, commit less serious offenses, or offend at a lower rate because of the fear of a future sanction (Spohn and Holleran 2002). ${ }^{2}$ The stiffer the punishment, the more the punished will try to avoid future punishments, and the higher the deterrent effect of the punishment. It can be expected that - even though imprisonment and community service are exchangeable for the (Dutch) criminal law the 'pains of imprisonment' (Windzio 2006) are more severe than the 'pains' of community service. Consequently, the deterrent effect of community service can be expected to be less strong than the deterrent effect of imprisonment. Therefore, deterrence theory leads to the hypothesis that community service will lead to higher post-sentencing recidivism rates than imprisonment.

On the other hand, there are several theories that predict benefits from community service compared to imprisonment in dampening recidivism. Differential association and learning theories, for example, assume that criminal behavior is learned through interaction and communication processes with others who are in favor of breaking the criminal law (Sutherland 1947; Akers 1997). From this perspective, prisons are seen as 'schools of crime' where offenders meet each other and learn deviant attitudes and criminal behavior. The possibility to adopt deviant attitudes or learn criminal behavior from fellow-inmates applies considerably less to offenders sentenced to community service. Instead, community service is thought to rehabilitate offenders partly through contacts with conventional co-workers (Harris and Lo 2002).

\footnotetext{
${ }^{2}$ Specific deterrence - the discouraging effect of official sanctions on those who actually underwent these sanctions - can be distinguished from general deterrence - the discouraging effect official sanctions have on the population writ large. Here our focus is only on the effect of punishment on the punished.
} 
Control theories state that individuals have a natural tendency toward crime, and that bonds to conventional society can restrain individuals from committing criminal activities (e.g., Hirschi 1969; Sampson and Laub 1995). Differences in committing criminal activities exist through variation in the extent to which people believe in societal norms, are attached to non-deviant others, and are involved and committed to conventional activities. Individuals refrain from crime out of fear that crime would eliminate accrued benefits developing from a life of conformity. Specifically, imprisonment may 'knife off' conventional bonds to family or work which are believed to reduce criminal activity (Sampson and Laub 1995). In contrast, community service is intended to maintain or even strengthen these bonds (Bazemore and Maloney 1994). Therefore, it is expected that imprisonment will diminish social control more so than will community service and thus lead to higher recidivism rates.

Finally, labeling theory suggests that official interventions contribute to the development of a criminal career rather than prevent offenders from living a life of crime (Becker 1963; Bernburg and Krohn 2003). Deviant labeling and official labeling in particular can lead to economic and social stigmatization (Pettit and Western 2004), increasingly block opportunities for a conventional life (Becker 1963; Farrington 1977; Bernburg and Krohn 2003), and progressively isolate offenders from the law abiding community thus fostering their return to committing criminal activities (McAlinden 2005). In comparing community service with imprisonment, community service is conceived as the more humane sanction precisely because it is presumed to be less stigmatizing compared to imprisonment. If indeed ex-prisoners experience more economic and social stigmatization compared to offenders sentenced to community service (Harris and Lo 2002), recidivism can be expected to be higher among ex-prisoners than among those who served community service.

Summarizing, extant criminological theories do not provide us with a clear and equivocal answer as different criminological theories lead to contradicting hypotheses about the extent to which recidivism will be more or less after community service than after imprisonment. Sound empirical research comparing recidivism after community service to that after imprisonment is therefore needed.

\section{Prior research and current focus}

Two recent systematic reviews examining the effects of imprisonment versus alternative sanctions (Villetaz et al. 2006; Nagin et al. 2009) found that out of the approximately 3,000 studies that were examined, only four studies using three datasets assessed the effect of community service on recidivism compared to imprisonment using (quasi-) experimental design. ${ }^{3}$ A Dutch review study (Van Noije and Wittebrood 2008) mentions two additional quasi-experimental studies conducted in The Netherlands. All studies used official data. None of these studies finds

\footnotetext{
${ }^{3}$ Various other (quasi-)experimental studies have examined the effects of imprisonment, however, not compared to community service, but to, for example, a fine, prosecutorial waiver, or pardon (see, e.g., Van der Werff 1979; Nieuwbeerta et al. 2009). Her,e we only overview those studies that compared recidivism after imprisonment with that after community service for adult offenders.
} 
recidivism to be higher after community service. Three studies (Killias et al. 2000; Gilliéron et al. 2006; Muiluvuori 2001) find no significant difference while the other three studies (Bol and Overwater 1986; Nirel et al. 1997; Spaans 1994) find recidivism of those who have performed a community service to be lower than that of those who experienced imprisonment. ${ }^{4}$

The first experimental study (Killias et al. 2000), which was conducted in Switzerland, compared recidivism rates after community service to that after imprisonment of a sample of adult offenders. In this study offenders were randomly distributed to either community service $(n=84)$ or short-term imprisonment up to 14 days $(n=39)$. One day imprisoned was considered equal to eight hours of work. Results from this study show that ,over a follow-up period of two years, recidivism after short-term imprisonment is higher than after community service. ${ }^{5}$ Ex-prisoners also developed more unfavorable attitudes towards their sentence and the criminal justice system than offenders sentenced to community service. However, 11 years after the experiment, the differences in recidivism between the two groups had disappeared, and it even seemed that offenders sentenced to imprisonment during the original experiment were integrated in the conventional society even better than offenders sentenced to community service (Gilliéron et al. 2006). Still, while experimental in design, two limitations can be identified in the random allocation procedures of this study. First, in the end, offenders preserved the right to choose a short-term imprisonment over the community service. Second, the Correctional Service also retained the right to decide that certain offenders could not be sentenced to community service.

In addition to the randomized experimental studies, four quasi-experimental studies have been carried out. First, a Finnish study by Muiluvuori (2001) used data on offenders from the years 1991-1992, when community service was regionally introduced in Finland on an experimental basis. Offenders imprisoned up to eight months were included in the control group. This study applied a matching by variable strategy with respect to sex, age, the length of the sentence, and criminal history, which was measured by the number of spells previously spent in prison. The use of times imprisoned as a proxy for the criminal history of offenders is questionable, since only a small share of the criminal history is accounted for this way. ${ }^{6}$ Moreover, including offenders who spent prior spells in prison in the analyses is problematic, since it is uncertain whether the effect of community service is confounded by the effects of prior imprisonment. Results show that, using a followup period of five years for offenders aged 15 or older, recidivism after community service $(n=303)$ is lower than after imprisonment $(n=302)$. Results further show that this finding holds for offenders in every other age category distinguished in this

\footnotetext{
${ }^{4}$ Studies using regression techniques generally show that differences in recidivism rates that favor alternative sanctions diminish when more control variables are added to the model (Nagin et al. 2009). This again underlines the importance of using a (quasi-)experimental design comparing the treated with adequate controls when trying to estimate the effects of non-custodial versus custodial sanctions.

5 This difference in recidivism was found not to be significant.

${ }^{6}$ The authors address in their study that previous time spent in prison was not a sufficient determinant of criminal history of offenders. There is a statistically almost significant difference found in terms of unconditional prison sentences during the three years preceding the sentence between the experimental and control groups.
} 
study. However, when prior imprisonment of offenders is taken into account, this effect is no longer significant.

Nirel et al. (1997) compared the recidivism rate of 407 Israeli offenders sentenced to community service to that of 950 offenders sentenced to imprisonment for maximally six months. The follow-up period was 14 months. Unlike in The Netherlands, in Israel offenders sentenced to community service are expected to work on a full-time basis. This study used propensity score matching to account for selection effects. Results show that offenders sentenced to community service and offenders sentenced to imprisonment differ significantly on many confounders. Service workers were generally older than prisoners, had a higher probability of being married, and had experienced fewer prior imprisonment spells. Propensity score matching succeeded in balancing these confounding variables between the two groups. Naive comparisons showed that the odds to recidivate were 2.4 times higher for exprisoners than ex-service workers. Matching on the propensity of receiving community service substantially reduced the apparent advantage of service work by one third.

The study by Bol and Overwater (1986) was conducted during the time community service was introduced on an experimental basis in The Netherlands. Adult offenders sentenced to imprisonment with a maximum of three months $(n=$ $217)$ in 1980 were compared with offenders sentenced to community service $(n=$ 217) using the matching by variable strategy. Offenders sentenced to community service and offenders sentenced to imprisonment were made comparable with respect to index offense, age, criminal history, and presumption of drug addiction. Offenders sentenced to community service included in the study however, were not a random sample of the total number of offenders sentenced to community service in 1980. Results show that over a follow-up period of 3.5 years recidivism after community service is lower than after a short-term imprisonment.

Finally, the study by Spaans (1994) compared recidivism rates of Dutch offenders sentenced to community service $(n=902)$ with offenders sentenced to imprisonment $(n=946)$ in 1986 or the first month of 1987 . The maximum imprisonment included in analysis was six months. Offenders sentenced to community service and offenders sentenced to imprisonment were made comparable with respect to age, gender, nationality, and index offense. No balance was reached on the criminal history of the offenders, since offenders sentenced to imprisonment had a more extensive criminal history compared to those sentenced to community service. Results show that over a follow-up period of 3.5 years offenders recidivate less after community service than after imprisonment.

Despite the (quasi-)experimental design, the above-mentioned studies show some methodological shortcomings that might bias the results. First, the majority of these studies were based on small samples, were geographically limited, and only analyzed male offenders compromising the generalizability of the obtained results. Second, except from the Swiss study, all prior studies have a short follow-up period. As a result, we know little about the long-term effects of community service compared to imprisonment. Third, the set of confounding variables controlled for in most studies is not extensive, which increases the likelihood that even after matching groups still differ on relevant unobserved covariates. Finally, making causal inferences from these studies is further complicated by possible spill-over effects of prior prison spells. 
The current study aims to extend prior research in multiple ways. First, we use a largescale dataset that includes very detailed information of all offenders sentenced to community service or imprisonment in The Netherlands in 1997. Second, these data provide us with a follow-up period of eight years which gives us insight in the recidivism occurring after either of these sanctions both in the short-term as well as in the long-term. Third, in order to minimize selection bias in our results, we use a combined method of 'matching by variable' and 'matching on propensity scores' to make offenders sentenced to community service and offenders sentenced to imprisonment as comparable as possible on confounding variables. Fourth, to test the robustness of our results against bias from unobserved covariates, we apply the Rosenbaum bounds method. Finally, to prevent interference from feed-back effects, our analyses are limited to offenders who were not previously sentenced to either community service or imprisonment.

\section{Data and operationalization}

To answer our research question, we analyze data that were made available by the Research and Documentation Centre (WODC) of The Netherlands Ministry of Justice. The data stem from the General Documentation Files (GDF) of the Criminal Record Office ('rapsheets') and contain information on every criminal case registered by the police at the Public Prosecutor's Office of all 153,252 offenders convicted in 1997, of which 16,561 where sentenced to community service and 15,797 to imprisonment.

Recorded conviction careers of all offenders sentenced in 1997 were reconstructed using abstracts from the GDF as available in 2005. Consequently, the data include the entire officially recorded criminal history, i.e. the number of convictions per year, starting at age 12 up to the year $2005 .^{7}$ Entries in the GDF include all criminal cases that have led to any type of judicial action. However, in this study, we only use information on those offenses that were either followed by a conviction or a prosecutorial disposition due to policy reasons, thereby excluding offenses that resulted in an acquittal or a prosecutorial disposition due to insufficient evidence.

Next to criminal career information, the GDF data contains information on other, known as confounding variables, such as sex, age, nationality, type of index offense, number of crimes in case of conviction, and severity of the offense. The GDF also contain information on the length of community service and the length of imprisonment following a conviction. This extra information is used to control for selection effects.

The overall sample size is reduced for comparison for various reasons. First, our analysis focuses on offenders aged between 18 and 50 years. We, therefore, exclude 6,340 offenders aged younger than 18 and older than $50 .{ }^{8}$ Second, offenders sentenced to either community service or imprisonment prior to their conviction in

\footnotetext{
${ }^{7}$ In The Netherlands, the minimum age of criminal responsibility is 12 years. Furthermore, individuals are not given a 'blank sheet' upon becoming an adult in The Netherlands.

${ }^{8}$ The decision to only include offenders aged 18 to 50 is made for various reasons. First, the largest share of offenders sentenced to community service was in this age-range (92.5\%). Second, for under-aged, other arrangements are valid compared with adult offenders. In order to decrease heterogeneity within each group, we choose to only analyze adult offenders.
} 
1997 were excluded to prevent interference from feed-back effects $(n=12,698)$. Feed-back effects would imply a prior sanction to affect both the chances of a subsequent community service and imprisonment as well as post-sanction recidivism. Third, considering the official rule stated in the Criminal Code applicable in 1997 that community service could replace imprisonment of maximally six months, offenders first imprisoned longer than six months were also excluded ( $n=$ 1,972). Finally, those offenders sentenced to both community service and imprisonment in 1997 were excluded $(n=40)$. These restrictions resulted in an analysis sample of 11,308 offenders, of which 7,806 were sentenced to community service and 3,502 to imprisonment. All sentences involving detention, including being placed in a reformatory school, of maximally six months were counted as imprisonment. ${ }^{9}$

\section{Outcome measure}

The outcome variable in our study is the post-treatment conviction rate. All convictions after the index offense are measured as recidivism, even when these subsequent convictions took place in 1997. The index offense was defined as an offender's first 1997 conviction that led to either community service or imprisonment. Since we have data up to 2005 , our follow-up period spans a maximum of eight years.

When applicable, in constructing our outcome variable, we control for the duration of incapacitation by multiplying the observed number of convictions by the inverse of the proportion of the follow-up period offenders were actually free to offend. We thereby assume that offenders would have been convicted at the same rate for the entire period if they had not been imprisoned.

Variables used in the matching procedures

When comparing two types of criminal justice interventions the list of potential confounding variables is endless. Nagin et al. (2009) state that to reach an acceptable base of comparison between groups two case characteristic variables - criminal history and conviction offense type - and three demographic variables - age, race, and sex - shoulddefinitely be accounted for. Our model includes these variables and adds even more.

To take case characteristics into account, we include 18 dummies representing offense types of the index offense (see Table 1). A continuous variable indicating the severity of the offense based on the maximum penalty is also included in the model (ranging from 0 to 20). Next, the number of crimes in case of conviction in 1997 was added to the model. Furthermore, we take into account the criminal history in great detail. In total, six variables are included concerning the criminal history of offenders. Distinctions are made between property crimes, violent crimes, and other

\footnotetext{
9 To put our sample in a proper Dutch perspective: in 1997, of all offenders sentenced to imprisonment (first time or otherwise), $72.6 \%$ were sentenced to six months imprisonment or less. Sentencing practices in The Netherlands are therefore quite different and more lenient than the United States. The, by U.S. standards, short prison sentences in The Netherlands, however, do not necessarily imply that most of the individuals sentenced to these short prison terms are also minor offenders by U.S. standards.
} 
crimes, and between the criminal history in the year prior to the index offense and the past ten years.

To take the demographic background into account, age (divided by ten) is added to our model as a continuous variable and quadratic to allow for a non-linear relationship between age and the chance of community service. Our model also includes dummy variables indicating whether the offender was male or female and whether the offender was born in The Netherlands or not.

In addition, prior to matching on propensity scores we match by different age categories, sex, and sentence-length. For the matching by variable, we distinguish seven age-categories. ${ }^{10}$ For the length of the sentence, we distinguish six categories, by which the classification of community service and imprisonment follows article $22 \mathrm{~b}$ of the Criminal Code at which community service up to 60 hours can replace one month imprisonment (Schuyt 2008). The first category thus includes community service up to 60 hours and prison sentences up to one month. Subsequent categories for community service are chosen at a smaller range so that the maximum of 240 hours is not exceeded. ${ }^{11}$ We match by sentence length to prevent comparing offenders having preformed a minimum amount (e.g., 40 hours) of community service to offenders having served a maximum amount (e.g., 6 months) of imprisonment.

Table 1 presents descriptive information on the variables included in analyses. A naïve comparison of recidivism rates shows that one year after community service, offenders recidivate on average 0.25 times, and one year after imprisonment, offenders recidivate on average 0.65 times. During a follow-up of eight years offenders recidivate on average 1.70 times after community service and 3.33 times after imprisonment. The mean age of those offenders sentenced to community service was 30.1 and 28.9 years for the imprisoned group (Table 1). Furthermore, of the offenders sentenced to community service, $18.3 \%$ were female and $32.1 \%$ were non-native, whereas of the imprisoned, $12.2 \%$ were female and $68.6 \%$ were non-native. Also, in 1997, at the moment of conviction for the index offense, the offenders sentenced to community sentence had on average 0.81 offenses in their criminal history (measured back to 1987) and the imprisoned group had on average 0.90 prior offenses. ${ }^{12}$ The length of community service varied from 1 to 240 hours, with a mean length of 106 hours, whereas the length of the imprisonment varied from one day to six months with a mean of 60.3 days. The distribution of the length of imprisonment is skewed-half of the imprisoned had a sentence up to two months. The number of offenders sentenced to longer imprisonment than two months is remarkably lower. This again underlines that the results of our analyses should not be generalized to the entire population of imprisoned. They apply only to those sentenced to short-term imprisonment (but see footnote 9).

\footnotetext{
10 The categorization of age: (1) $18-21$; (2) $22-25$; ... (6) 41-45; (7) 46-50.

11 The categorization of length of sentence: (1) community service up to 61 hours or up to 1 month imprisonment; (2) community service of $61-113$ hours or $1-2$ months imprisonment; (3) community service of 113-157 hours or 2-3 months imprisonment; (4) community service of 157-197 hours or 34 months imprisonment; (5) community service of 197-221 hours or 4-5 months imprisonment; (6) community service of 221-241 hours or 5-6 months imprisonment.

12 Note that to prevent interference from feed-back effects, all offenders who were previously sentenced to either community service or imprisonment were excluded from analysis. The criminal history of the offenders is thus related to, for example, fines.
} 
Table 1 Means and standard deviations of offenders sentenced to community service $(n=7,806)$ and offenders sentenced to imprisonment $(3,502)$ in 1997: full sample

\begin{tabular}{|c|c|c|c|c|}
\hline & \multicolumn{2}{|c|}{ Community service } & \multicolumn{2}{|c|}{ Imprisonment } \\
\hline & Mean & SD & Mean & SD \\
\hline \multicolumn{5}{|l|}{ Recidivism } \\
\hline No. crimes 1 year follow-up & 0.246 & 0.910 & 0.646 & 4.649 \\
\hline No. crimes 3 years follow-up & 0.740 & 1.950 & 1.641 & 4.280 \\
\hline No. crimes 5 years follow-up & 1.160 & 2.898 & 2.428 & 6.244 \\
\hline No. crimes 8 years follow-up & 1.698 & 3.915 & 3.333 & 8.420 \\
\hline \multicolumn{5}{|l|}{ Social demographics } \\
\hline Female & 0.183 & & 0.122 & \\
\hline Age & 30.118 & 8.866 & 28.913 & 7.658 \\
\hline Non-native & 0.321 & & 0.686 & \\
\hline \multicolumn{5}{|l|}{ Type of offense/ conviction } \\
\hline Other non-criminal law & 0.078 & & 0.059 & \\
\hline Trespass & 0.000 & & 0.002 & \\
\hline Public violence & 0.056 & & 0.021 & \\
\hline Offense against authority & 0.002 & & 0.002 & \\
\hline Public order & 0.015 & & 0.009 & \\
\hline Aggressive severe injury & 0.043 & & 0.027 & \\
\hline Insulting & 0.000 & & 0.001 & \\
\hline Threatening, assault & 0.043 & & 0.043 & \\
\hline Aggrevated assault & 0.013 & & 0.010 & \\
\hline Arson endangering human life & 0.007 & & 0.006 & \\
\hline Other, cruelty to animals & 0.016 & & 0.013 & \\
\hline Violent sexual & 0.008 & & 0.006 & \\
\hline Fornication younger than 16 years & 0.024 & & 0.010 & \\
\hline Fencing & 0.278 & & 0.189 & \\
\hline Property & 0.051 & & 0.099 & \\
\hline Theft & 0.147 & & 0.228 & \\
\hline Violent theft & 0.031 & & 0.044 & \\
\hline Traffic & 0.086 & & 0.051 & \\
\hline Opium act & 0.088 & & 0.158 & \\
\hline Weapons act & 0.017 & & 0.023 & \\
\hline \multicolumn{5}{|l|}{ Criminal history } \\
\hline Number of property crimes past year & 0.038 & 0.241 & 0.089 & 0.416 \\
\hline Number of violent crimes past year & 0.017 & 0.144 & 0.021 & 0.167 \\
\hline Number of other crimes past year & 0.065 & 0.301 & 0.594 & 0.293 \\
\hline Number of property crimes past ten years & 0.241 & 0.705 & 0.301 & 0.867 \\
\hline Number of violent crimes past ten years & 0.100 & 0.382 & 0.087 & 0.356 \\
\hline Number of other crimes past ten years & 0.353 & 0.836 & 0.339 & 0.872 \\
\hline \multicolumn{5}{|l|}{ Index offense } \\
\hline Number of crimes in case of conviction & 1.626 & 0.968 & 1.541 & 0.900 \\
\hline
\end{tabular}


Table 1 (continued)

\begin{tabular}{lccccc}
\hline & \multicolumn{2}{l}{ Community service } & & \multicolumn{2}{l}{ Imprisonment } \\
\cline { 2 - 3 } & Mean & SD & & Mean & SD \\
\hline Severity of offense & 4.547 & 3.022 & & 4.140 & 2.920 \\
Length community service (in hours) & 105.706 & 66.672 & & \\
Length imprisonment (in days) & & & & 60.330 & 49.278 \\
\hline
\end{tabular}

\section{Methods: a matched samples approach}

The objective of this paper is to compare recidivism after community service to recidivism after imprisonment. The optimal design to make such a comparison would be a randomized experiment in which offenders are randomly allocated either to community service or short-term imprisonment. The random allocation would control extraneous influences by equating them in the two groups. However, randomized experiments are difficult to come by in a criminal justice setting. In practice therefore analysis using non-experimental observational data is more feasible. When using observational data selection processes will tend to make the community service group less crime prone compared to the imprisoned group.

In this paper, we use the 'matching by variable strategy' and 'propensity score matching strategy' to maximally account for these selection processes. After estimating the propensity scores, offenders sentenced to community service (experimental group) are first matched by three different variables to offenders sentenced to imprisonment (control group) and thereafter matched by their propensity scores. Second, after matching on propensity scores, the absolute and relative treatment effects are estimated - that is, the absolute and relative difference in recidivism after community service and after imprisonment.

\section{Matching by variable method}

First, as indicated above, we match offenders from the experimental group one by one to offenders in the control group by age category, sex, and length of the sentence. These variables were also used by Muiluvuori (2001) to control for selection into treatment. We use this strategy in addition to matching on propensity scores, since propensity score matching does not guarantee that, for example, female offenders are matched to female offenders and that matched offenders are in the same age category. Furthermore, by using this method, we are able to take the length of community service and imprisonment into account.

Propensity score model

Second, propensity score matching is used to control for selection effects. Propensity score matching is specifically designed to achieve balance on the observed covariates between the experimental and control group (Rosenbaum and Rubin 
1983, 1984; Haviland et al. 2007; see also Nieuwbeerta et al. 2009). The propensity score is the conditional probability of receiving treatment given the observed covariates. In this study, the propensity score is the conditional probability of community service at age $t$ given observed covariates up to $t$ versus imprisonment. The propensity score is estimated using a logistic regression model (Cox and Snell 1989). Models using propensity scores are more robust concerning model misspecification compared to models based on regression techniques (Drake 1993). Furthermore, results from propensity score adjustments have been shown to approximate results from randomized experiments (see, for more information, Shadish et al. 2008).

Table 2 shows the results of the logistic regression estimates for the propensity score model. Most covariates significantly influence the chance of being sentenced to community service. For example, the odds for female offenders to be sentenced to community service versus imprisonment are 1.50 times higher than that for male offenders. Furthermore, Dutch-born offenders have an odds of being sentenced to community service that is five times higher than that of non-Dutch-born offenders. Younger offenders are also more likely to be sentenced to community service than older offenders. Compared to offenses in the category non-criminal law, the likelihood of being sentenced to imprisonment rather than community service is higher for most offense types: especially violent theft and arson endangering human life are significant predictors of being sentenced to imprisonment.

\section{Common support}

Based on the propensity score model, a predicted probability to being sentenced to community service - the propensity score - can be estimated for each individual offender. Figure 1 shows the distribution of estimated propensity scores for the experimental and control group. Clearly, the majority of offenders having the highest propensity scores based on the observed covariates were actually sentenced to community sentence. Still, there is sufficient overlap-common support-between the propensity score distribution of the experimental group and that of the control group. With this level of common support, the results do not relate to only a select (non-representative) part of the offenders in the experimental or the control groups. Figure 1 therefore indicates that propensity score matching is a suitable method for this data.

\section{Matching by propensity scores}

Offenders from the experimental group are matched one by one, without replacement, to offenders from the control group with a comparable propensity score using a calliper of 0.05 . As a result, an individual in the control group will be matched to an individual in the experimental group in such a way that the multivariate pre-treatment covariate distance is minimized. That is, the difference between the predictors in the propensity score model is minimized across the two groups. The difference between the imprisoned and the comparison group is calibrated by two types of statistical measures. One is the conventional two-sample $t$ statistic and the other is a standardized difference statistic in percentages, suggested 
Table 2 Determinants of receiving community service in 1997 ( $n=11,308$ of which 7,806 coded 'community service' and 3,502 'imprisoned')

\begin{tabular}{|c|c|c|c|c|}
\hline & Coefficient & SE & Significance & $\operatorname{Exp}(B)$ \\
\hline \multicolumn{5}{|l|}{ Social demographics } \\
\hline Female & 0.405 & 0.067 & $* * *$ & 1.499 \\
\hline Age $(/ 10)$ & -1.286 & 0.217 & $* * *$ & 0.276 \\
\hline Age_squared (/10) & 0.207 & 0.034 & $* * *$ & 1.230 \\
\hline Non-native & -1.611 & 0.048 & $* * *$ & 0.200 \\
\hline \multicolumn{5}{|l|}{ Type of offense/ conviction } \\
\hline Other non-criminal law & (ref.) & (ref.) & & (ref.) \\
\hline Trespass & -1.407 & 0.863 & $*$ & 0.245 \\
\hline Public violence & -0.035 & 0.174 & & 0.966 \\
\hline Offense against authority & -0.245 & 0.497 & & 0.783 \\
\hline Public order & -0.318 & 0.237 & & 0.728 \\
\hline Aggressive severe injury & -0.443 & 0.182 & $* * *$ & 0.642 \\
\hline Insulting & -2.087 & 1.295 & & 0.124 \\
\hline Threatening, assault & -0.365 & 0.139 & $* * *$ & 0.694 \\
\hline Aggravated assault & -0.600 & 0.237 & $* * *$ & 0.549 \\
\hline Arson endangering human life & -1.976 & 0.364 & $* * *$ & 0.139 \\
\hline Other, cruelty to animals & -0.808 & 0.219 & $* * *$ & 0.446 \\
\hline Violent sexual & -0.999 & 0.315 & $* * *$ & 0.368 \\
\hline Fornication younger than 16 years & -0.630 & 0.230 & $* * *$ & 0.533 \\
\hline Fencing & -0.087 & 0.122 & & 0.917 \\
\hline Property & -1.258 & 0.128 & $* * *$ & 0.284 \\
\hline Theft & -1.268 & 0.127 & $* * *$ & 0.281 \\
\hline Violent theft & -1.606 & 0.203 & $* * *$ & 0.201 \\
\hline Traffic & 0.194 & 0.130 & & 1.214 \\
\hline Opium act & -0.585 & 0.108 & $* * *$ & 0.557 \\
\hline Weapons act & -0.170 & 0.179 & & 0.843 \\
\hline Number of crimes in case of conviction & 0.079 & 0.026 & $* * *$ & 1.082 \\
\hline Severity of offense & 0.111 & 0.017 & $* * *$ & 1.118 \\
\hline \multicolumn{5}{|l|}{ Criminal history } \\
\hline Number of property crimes past year & -0.358 & 0.072 & $* * *$ & 0.699 \\
\hline Number of violent crimes past year & -0.276 & 0.143 & $* *$ & 0.759 \\
\hline Number of other crimes past year & 0.026 & 0.078 & & 1.026 \\
\hline Number of property crimes past ten years & -0.028 & 0.030 & & 0.973 \\
\hline Number of violent crimes past ten years & 0.027 & 0.063 & & 1.027 \\
\hline Number of other crimes past ten years & -0.093 & 0.028 & $* * *$ & 0.911 \\
\hline Constant & 3.412 & 0.351 & $* * *$ & 30.340 \\
\hline
\end{tabular}




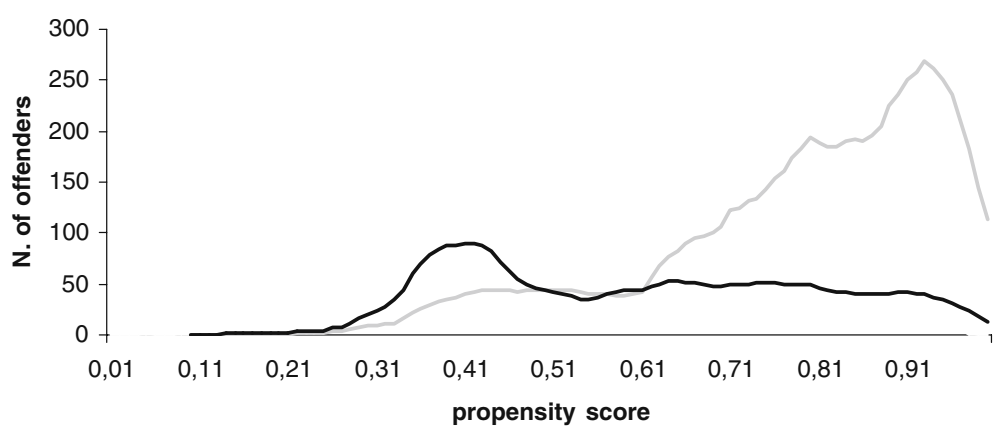

10 per. Mov. Avg. (experimental group) -10 per. Mov. Avg. (control group)

Fig. 1 Distribution of propensity scores of community service (experimental group) and imprisonment (control group) in full sample $(11,308)$

by Rosenbaum and Rubin (1985:36) ${ }^{13}$. According to Rosenbaum and Rubin, the characteristic between the experimental and control group is out of balance when the absolute value of the standardized difference D is greater than 20 .

\section{Matching result}

Since the number of offenders in the control group $(n=3,502)$ is smaller than the number in the experimental group $(n=7,806)$, it was not possible to find a match for every offender in the experimental group. When all controls are used, we can maximally match $45 \%$ of the offenders in the experimental group. In this study,we matched 2,116 offenders from the experimental group to 2,116 offenders from the control group. We thus were able to find a match for over $60 \%$ of the maximum possible number of matches for the experimental group (Table 3 ).

Offenders from the experimental group for which we were unable to find a match differ from offenders in the experimental group that we could match. The propensity scores of the unmatched offenders in the experimental group were high compared to those of offenders we were able to find a match for; these offenders were too different in terms of observed variables from offenders in the control group. Furthermore, female offenders are underrepresented in the matched sample. Matched and unmatched offenders did not differ with regard to their age in 1997.

\section{Balance}

Table 3 (upper) shows that the community service group and the imprisoned group differ significantly on most of the observed variables. The offenders sentenced to

13 The formula for the standardized difference statistic - in percentages - as suggested by Rosenbaum and Rubin (1985:36) is:

$$
D=\left(\frac{X_{w}-X_{n}}{\sqrt{\frac{s_{w}^{2}+s_{n}^{2}}{2}}}\right) * 100
$$




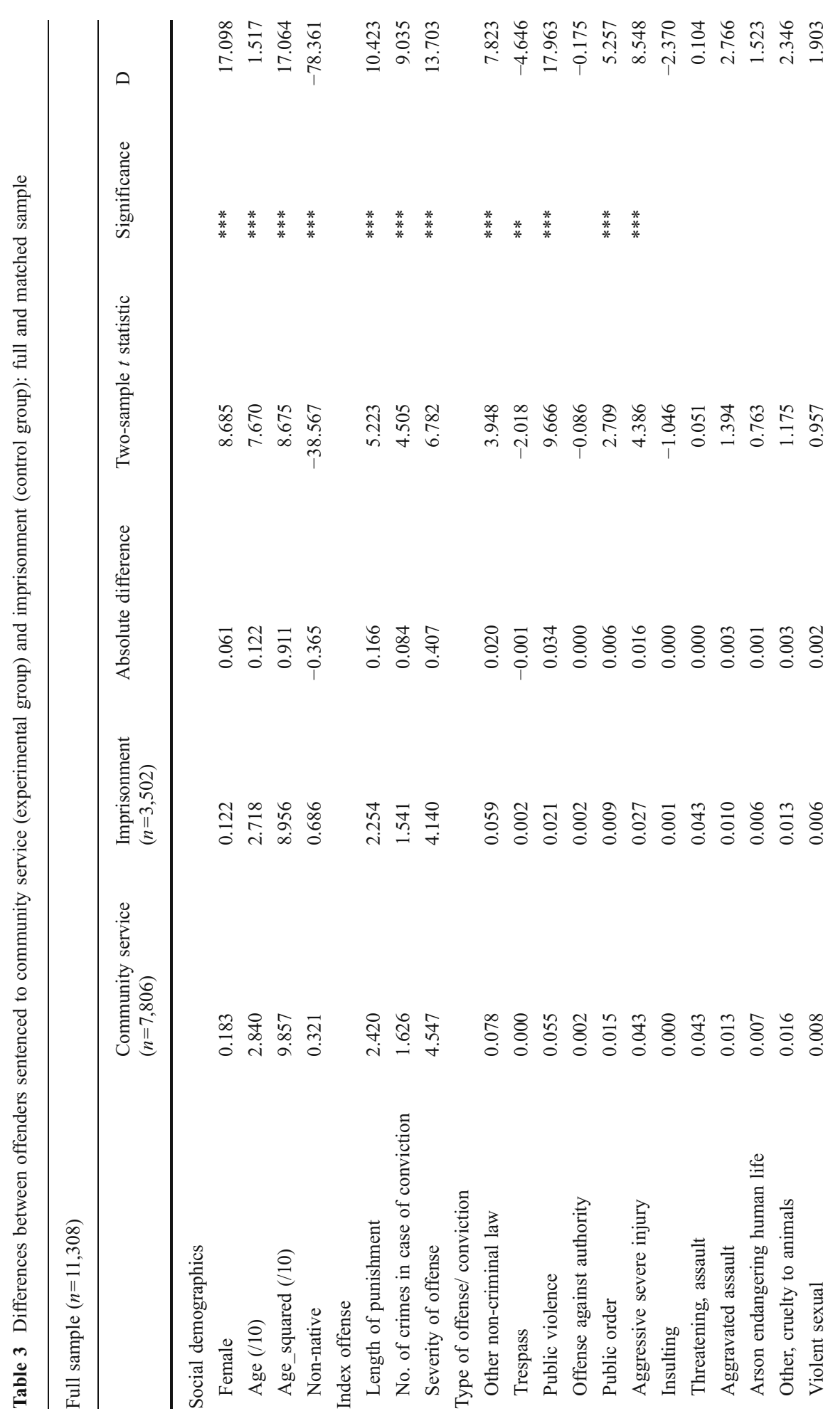




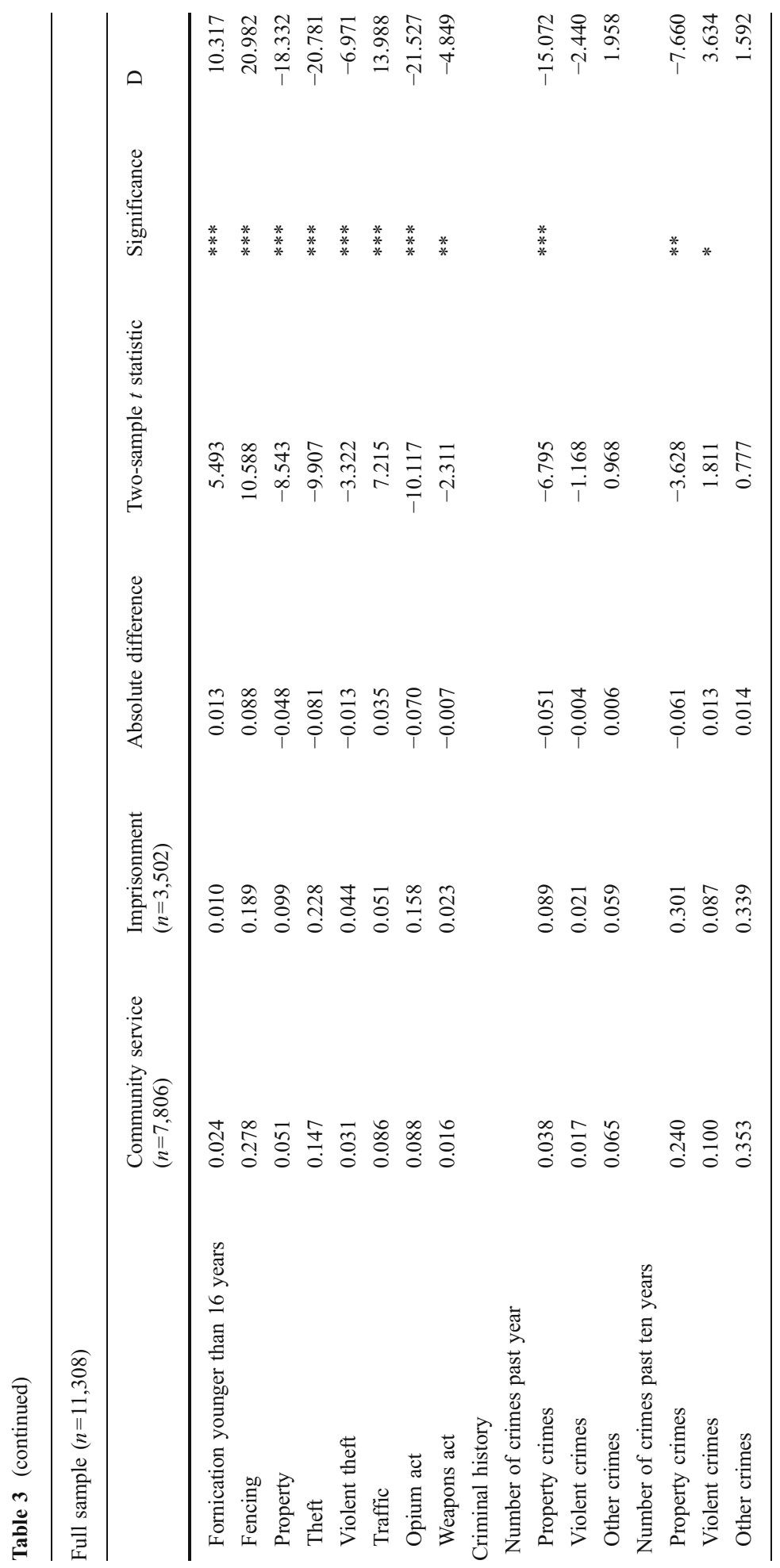




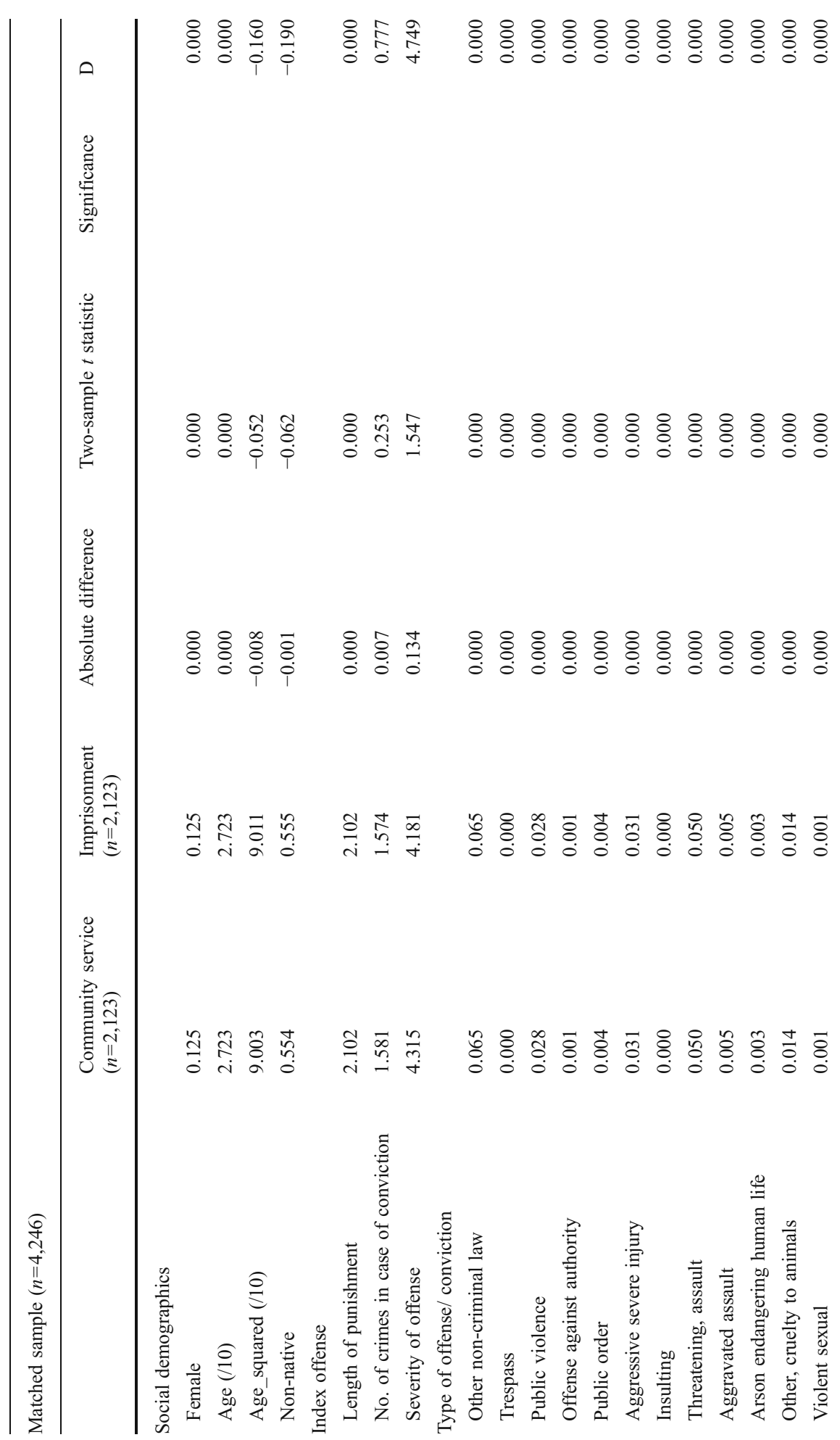




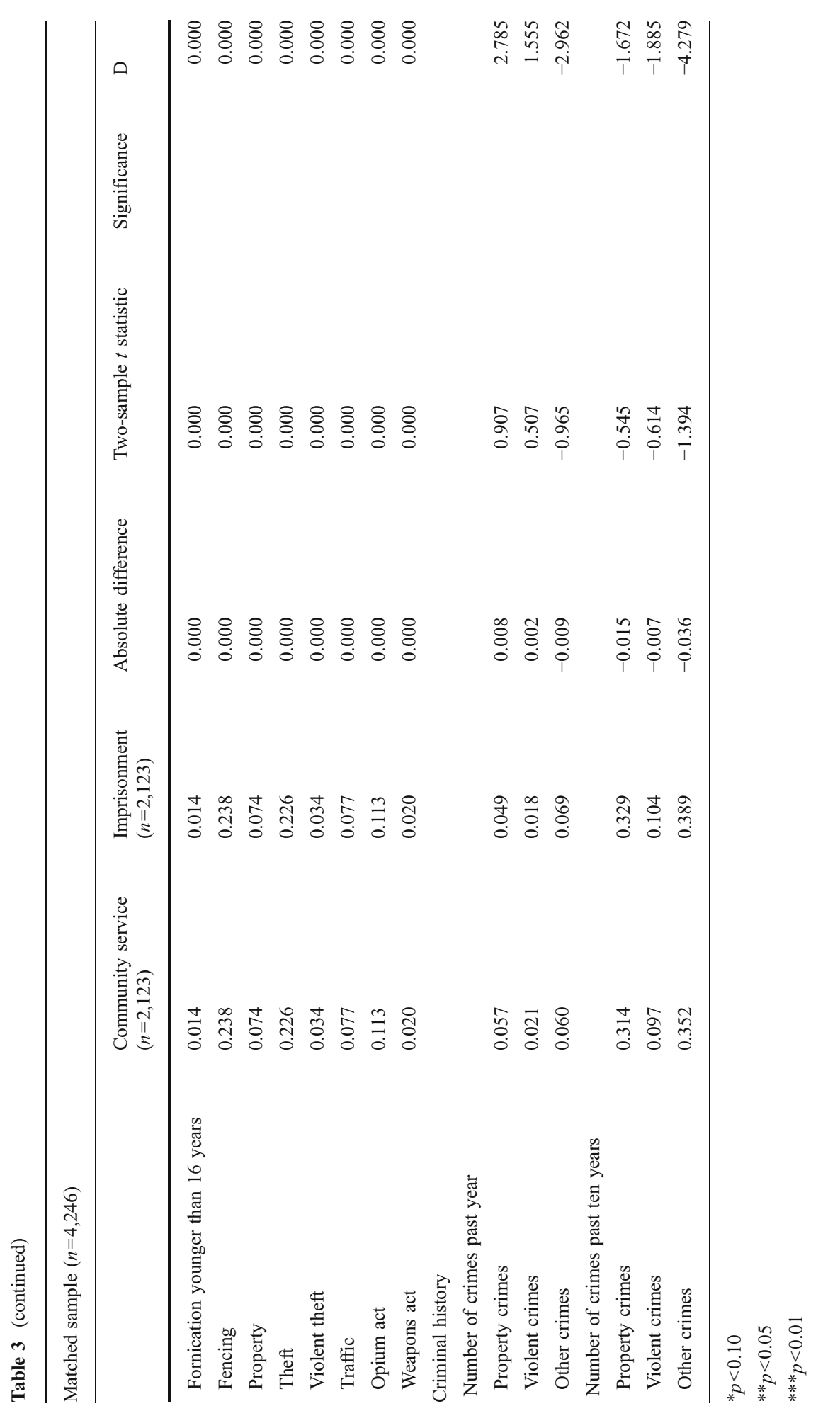


community service are, for example, more likely to be Dutch-born and more likely to be female than are offenders sentenced to imprisonment. Furthermore, those sentenced to community service have a less extensive criminal history and are less likely to be sentenced for (violent) theft or a violation of the opium act. Table 3 (lower) shows that the combined method of matching by variable and matching on propensity scores was successful in creating balance on all observed covariates. After applying the matching strategies, no statistically significant differences between the experimental and control group remain. This implies that we can be confident that differences in post-sentence convictions do not reflect already existing differences in the observed variables between the experimental and control group.

\section{Results: effect of community service and imprisonment on recidivism}

After the matching process, both absolute and relative treatment effects are assessed. The absolute treatment effect refers to the absolute difference between the average recidivism rate after community service and that after imprisonment. The difference between the community service and imprisoned group is calibrated by the conventional two-sample $t$ statistic. When estimating the relative effects of community service on recidivism, it is taken into account that recidivism of men for example is higher than that of women and that of younger offenders is higher than older offenders, regardless whether sentenced to community service or imprisonment. The relative treatment effect equals the absolute treatment effect divided by the average recidivism rate in the control condition, that is after imprisonment, times 100. Consequently, the relative effect depicts the deviation of the base rate (mean recidivism of the control group) in percentages.

Table 4 provides the average recidivism rates after community service and imprisonment across different follow-up periods and different types of offenses. Recidivism is expressed in the yearly average number of convictions. Table 4 shows that the absolute treatment effect is negative and highly significant. The negative sign of the treatment effect suggests that community service leads to less recidivism than imprisonment. Not only are the treatment effects highly significant $(p<0.01)$, their magnitude is large. Over a five-year follow-up, for example, the difference is a yearly average of -0.242 convictions. Thus, during the five years after their firsttime community service, offenders attain 1.21 convictions $(5 \times-0.242)$ less than offenders after their first-time imprisonment. In relative terms, community service leads to a reduction in recidivism of $46.8 \%$ compared to recidivism after imprisonment.

Similar results are shown for different types of recidivism. The relative treatment effect shows that one year after community service, recidivism for property crimes is $67.7 \%$ less than that after imprisonment. For violent crimes, recidivism is reduced by $60 \%$. Comparing results for the different follow-up periods shows that the negative treatment effect of community service is stable over time. Of the 16 results for the absolute treatment effect, 15 are negative and statistically significant for a two-sided test $(p<0.05)$. The magnitude of the treatment effect does decrease slowly as the follow-up period increases. In short, our results show that recidivism after 
Table 4 Mean yearly recidivism rates and treatment effects for different follow-ups

\begin{tabular}{|c|c|c|c|c|c|c|}
\hline & $\begin{array}{l}\text { Community service } \\
(n=2,123)\end{array}$ & $\begin{array}{l}\text { Imprisonment } \\
(n=2,123)\end{array}$ & $\begin{array}{l}\text { Absolute } \\
\text { difference }\end{array}$ & $\begin{array}{l}\text { Two-sample } t \\
\text { statistic }\end{array}$ & Significance & $\begin{array}{l}\text { Relative } \\
\text { effect }\end{array}$ \\
\hline \multicolumn{7}{|l|}{1 year } \\
\hline Total & 0.273 & 0.683 & 0.410 & -3.229 & $* * *$ & -6.000 \\
\hline Property crimes & 0.132 & 0.398 & -0.266 & -2.404 & $* *$ & -0.677 \\
\hline Violent crimes & 0.044 & 0.109 & -0.065 & -2.255 & $* *$ & -0.600 \\
\hline Other crimes & 0.097 & 0.175 & -0.079 & -3.698 & $* * *$ & -0.448 \\
\hline \multicolumn{7}{|l|}{3 years } \\
\hline Total & 2.292 & 0.575 & -0.283 & -5.401 & $* * *$ & -0.492 \\
\hline Property crimes & 0.129 & 0.292 & -0.162 & -5.418 & $* * *$ & -0.557 \\
\hline Violent crimes & 0.052 & 0.100 & -0.049 & -2.755 & $* * *$ & -0.484 \\
\hline Other crimes & 0.111 & 0.183 & -0.072 & -2.048 & $* *$ & -0.395 \\
\hline \multicolumn{7}{|l|}{5 years } \\
\hline Total & 0.276 & 0.518 & -0.242 & -5.181 & $* * *$ & -0.468 \\
\hline Property crimes & 0.115 & 0.250 & -0.135 & -5.339 & $* * *$ & -0.539 \\
\hline Violent crimes & 0.053 & 0.096 & -0.043 & -2.645 & $* * *$ & -0.450 \\
\hline Other crimes & 0.108 & 0.172 & -0.064 & -2.000 & $* *$ & -0.373 \\
\hline \multicolumn{7}{|l|}{8 years } \\
\hline Total & 0.249 & 0.444 & -0.195 & -4.943 & $* * *$ & -0.439 \\
\hline Property crimes & 0.094 & 0.203 & -0.110 & -5.422 & $* * *$ & -0.540 \\
\hline Violent crimes & 0.049 & 0.086 & -0.037 & -2.770 & $* * *$ & -0.425 \\
\hline Other crimes & 0.106 & 0.155 & -0.049 & -1.497 & & -0.314 \\
\hline
\end{tabular}

$* p<0.10$

$* * p<0.05$

$* * * p<0.01$

community service is lower than that after imprisonment, for all offenses as well as for property and violent offenses separately. This effect of community service is noticeable both in the short-term as well as in the long-term.

Sensitivity of the treatment effects to hidden bias

While the use of by variable and propensity score matching secures balance on the observed confounders, there is always the danger of unobserved variables compromising the validity of inferring causality from observational data. Our propensity score model, for example, did not contain information about offenders' life circumstances, e.g., marital or employment status at the time of conviction. Prior research has shown that these personal characteristics influence both the likelihood of receiving certain types of sanctions, as well as the probability of recidivism (e.g., Spohn and Holleran 2002; Nieuwbeerta et al. 2009). If these unobserved variables simultaneously affect assignment into treatment and the outcome variable, a hidden bias might be present to which matching estimators are not robust (Rosenbaum 2002). 
Table 5 Rosenbaum bounds for the treatment effects for different follow-ups

\begin{tabular}{lllll}
\hline Total treatment effect & $\Gamma$ & $p$ critical & \multicolumn{2}{l}{ Hidden bias equivalents } \\
\cline { 3 - 4 } & & & $\begin{array}{l}\text { No. property offenses } \\
\text { last year }\end{array}$ & $\begin{array}{l}\text { No. violence offenses } \\
\text { last year }\end{array}$ \\
\hline 1 year follow-up & 1.45 & 0.045 & -1.039 & -1.348 \\
& 1.50 & 0.097 & -1.134 & -1.471 \\
3 years follow-up & 1.35 & 0.028 & -0.839 & -1.089 \\
& 1.40 & 0.093 & -0.941 & -1.221 \\
5 years follow-up & 1.25 & 0.011 & -0.624 & -0.809 \\
& 1.30 & 0.054 & -0.734 & -0.952 \\
8 years follow-up & 1.15 & 0.018 & -0.391 & -0.507 \\
& 1.20 & 0.092 & -0.510 & -0.661 \\
\hline
\end{tabular}

To get a sense of the robustness of our results against hidden bias, we determine the extent of selection on unobserved variables needed in order to undermine our implications of the matching analyses using the Rosenbaum bounds method (Rosenbaum 2002). In short, this method evaluates the sensitivity of the observed effects under a number of scenario's differing in the magnitude of unobserved confounding (DiPrete and Gangl 2004). ${ }^{14}$ A scenario of bound estimate $\Gamma=1$ is equivalent to no hidden bias. Bound-estimates higher than 1 represent the degree to which the treatment effects may be underestimated or overestimated because of unobserved confounding. For example, a scenario of $\Gamma=1.30$ assumes hidden bias that would increase the odds of receiving community service for the offenders actually sentenced to community service by $30 \%$ versus offenders sentenced to imprisonment.

Table 5 shows the robustness of our findings to hidden bias across the different follow-up periods. The significance level $p$ critical represents the bound on the significance level of the treatment effect in the case of endogenous selection into treatment status. Given the direction of our results a situation of positive selfselection will actually cause our findings to be conservative estimates. We therefore only focus on negative self-selection into treatment.

The results show that the critical level of $\Gamma$ at which the estimated treatment effect would render no longer significant at a 5\% level ranges from 1.50 to 1.20 . The longer the follow up, the least robust our findings are to selection effects. Thus, our conclusion that recidivism after community sentence is lower than that after imprisonment would need to be questioned if an unobserved variable would increase the odds of receiving community service for the offenders actually sentenced to community service by 20 to 50 percent versus offenders sentenced to imprisonment.

To illustrate the magnitude of hidden bias that would render our findings spurious, the critical levels expressed in Table 5 can be compared with the impact on

\footnotetext{
${ }^{14}$ To conduct the analysis, we invoke the user-written Stat routine - mhbounds-developed by Becker and Caliendo (2007)
} 
being sentenced to community service instead of imprisonment of observed variables, which impact is known from the propensity score model. The critical level of $\Gamma=1.50$ is attained if there is an unobserved covariate comparable to the magnitude of, for example, sex (see Table 2). Furthermore, Table 5 shows that, for example, for the one-year follow-up, the critical level of $\Gamma=1.50$ is reached at a difference in the number of property crimes in the year previous to the index offense of $1.134 .^{15}$ Considering the average number of property crimes for offenders sentenced to community service was 0.038 (Table 1), this amounts to a significant decrease in an individual's criminal history. Similarly, the critical level of hidden bias would need to equal a difference of 1.471 in the number of violent crimes in the previous year. Even for the eight-year follow-up the critical level of $\Gamma=1.20$ is still equivalent to a decrease in the number of property crimes in the previous year of -0.510 and a decrease in prior violent crimes of -0.661 . These results illustrate the level of hidden bias that could be in the data without changing the inference about the treatment effects.

\section{Discussion}

The objective of this study was to compare recidivism rates after first community service to that after first imprisonment (up to six months) in a sample of adult Dutch offenders convicted in 1997. We employed both matching by variable and propensity score matching to control for possible selection into sanction type. We also assessed the robustness of our results to hidden bias due to unobserved confounders.

Our results show that offenders recidivate significantly less after community service than after imprisonment. This result is in line with results from prior research (Bol and Overwater 1986; Killias et al. 2000; Nirel et al. 1997; Spaans 1994). In the short term as well as in the long term, community service is followed by less recidivism than imprisonment; nearly half as many reconvictions over an eight-year follow-up period. The absolute difference in recidivism after community service and imprisonment is 1.21 convictions after a follow-up period of five years. The strengths of our study are in the representativeness and size of the cohort, the detailed criminal history information available for the offenders in our sample, and the cutting edge methods used to account for selection effects. Among its weaknesses are its sole reliance on registered data and the unavailability of data on offenders' life course circumstances. It is also important to note that in the end our results are not based on a random experiment whereby offenders were randomly assigned to either community service or imprisonment. Therefore, caution is warranted when interpreting these results in terms of causality. Studies using observational data always remain vulnerable to hidden bias resulting from unobserved variables. Conducting true experiments that introduce randomness in the sentencing decision thus remains desirable. Still, the results of the sensitivity

$15\left(x=\frac{\log (\Gamma)}{\log (\exp (b))}\right)$ 
analysis give confidence that in the current study the observed differences in postsentence recidivism are unlikely to be due to pre-sentence selection effects. ${ }^{16}$

At this moment, our data do not allow any comprehensive evaluation of the causal mechanisms underlying our results. Yet, if indeed our findings point to a causal effect of community service relative to imprisonment, deterrence theory seems unlikely to be important in explaining differences in recidivism following these sanction types. Given that, in The Netherlands, community service is to be performed in the offender's spare time, leaving his or her daily routines and social network untouched, it seems implausible that the specific deterrent value of community service tops that of being incarcerated. With the required prudence, we can conclude from our results that deterrence does not play a dominant role in the total of effects of community service and imprisonment on recidivism.

Assessing the relative importance of learning, social control or labeling processes is clearly beyond the scope of our data, especially since these processes all seem to interlock. For future research, it is highly relevant to test causal structures behind the effect of official interventions on recidivism.

If our findings reflect an effect of community service relative to imprisonment, our results are of great relevance to policymakers. Incarcerating offenders is very costly compared to sentencing offenders to community service; in 2004 the total cost of imprisoning adult offenders in The Netherlands amounted to nearly one billion Euros (Moolenaar 2005). Even apart from the direct benefits resulting from the labor performed by community workers, imprisoning offenders in The Netherlands is currently approximately 8 times more costly than letting them perform community service. Imprisoning one offender for six months will cost the Dutch taxpayer 34,200 Euros, while the costs for 240 hours of community service replacing these six months of imprisonment amount to approximately 4,200 Euros (Moolenaar 2005; Junger-Tas 1994). So, if community service also results in less recidivism, the benefits resulting from these crimes prevented will further tip the balance in favor of community service. Furthermore, the humane costs of community service are lower as community services place emphasis on resocialization and reintegration and less on retribution. Nevertheless, it should be noted that imprisonment prevents offenders from committing crimes by physical isolation and might prevent individuals becoming first-offender via the principle of general deterrence. Furthermore, for victims of crime, imprisonment might satisfy feelings of retribution more than community service.

Thus, for the present, in terms of post-sentence recidivism as well as financially, community service seems to provide a good alternative for imprisonment. What is also noteworthy in this regard is that, despite the fact that first-time imprisonment in The Netherlands averages around two months, its negative effects compared to community service continue to resonate even over

\footnotetext{
${ }^{16}$ Another drawback of this study is that there remains a possibility that an undefined number of community services are converted to imprisonment in a later stadium, for example when offenders do not show up or complete their community service. Since imprisonment cannot halfway be converted in community service, any bias resulting from this will lead to an under- rather than an overestimation of the difference in post-sentence recidivism. Recent showed that approximately $86 \%$ of those offenders sentenced to community services make it successfully to an end in The Netherlands (van der Heide et al. 2004).
} 
an eight-year follow-up. That such short-term imprisonment is associated with long-term criminogenic effects is not encouraging in light of the expanded use of imprisonment in response to crime.

Acknowledgements The authors are grateful to Ineke Maas, Anne-Rigt Poortman for insightful suggestions and comments. The data used in this study were made available by the Research and Documentation Centre (WODC), Ministry of Justice, The Netherlands.

Open Access This article is distributed under the terms of the Creative Commons Attribution Noncommercial License which permits any noncommercial use, distribution, and reproduction in any medium, provided the original author(s) and source are credited.

\section{References}

Akers, R. L. (1997). Deviant behavior: A social learning approach (2nd ed.). Belmont: Wadsworth.

Bazemore, G., \& Maloney, D. (1994). Rehabilitating community service toward restorative service sanctions in a balanced justice system. Federal Probation, 58, 24-35.

Becker, G. S. (1963). Outsiders: Studies in the sociology of deviance. New York: Free Press.

Becker, S. O., \& Caliendo, M. (2007). Sensitivity analysis for average treatment effects. Stata Journal, 7 , 71-83.

Bernburg, J. G., \& Krohn, M. D. (2003). Labeling, life chances, and adult crime: the direct and indirect effects of official intervention in adolescence on crime in early adulthood. Criminology, 41, 12871318.

Bol, M. S. \& Overwater, J. J. (1986). Recidive van dienstverleners: In het strafrecht voor volwassenen. 's-Gravenhage: Staatsuitgeverij

Cox, D. R., \& Snell, E. J. (1989). Analysis of binary data. London: Chapman and Hall.

DiPrete, T., \& Gangl, M. (2004). Assessing bias in the estimation of causal effects: Rosenbaum bounds on matching estimators and instrumental variables estimation with imperfect instruments. Sociological Methodology, 34, 271-310.

Drake, C. (1993). Effects of the propensity score on estimators of treatment effect. Biometrics, 49, 1231-1236.

Farrington, D. P. (1977). The effects of public labelling. British Journal of Criminology, 17, 112-125.

Gilliéron, G., Poglia, C., Villard, F., Vuille, J., Perisset, C. \& Killias, M. (2006). Bessere Resozialisierung nach gemeinnütziger Arbeit? Ein Vergleich mit kurzen Freiheitsstrafen - 11 Jahre später. Crimiscope Nr. 34. ESC - UNIL - Lausanne. Abrufbar unter www.unil.ch/esc/page19064.html

Harris, M. K. (1979). Community service by offenders. Washington, D.C.: American Bar Association.

Harris, R. J., \& Lo, T. W. (2002). Community service: its use in criminal justice. International Journal of Offender Therapy and Comparative Criminology, 46, 427-444.

Haviland, A., Nagin, D. S., \& Rosenbaum, P. R. (2007). Combining propensity score matching and group-based trajectory analysis in an observational study. Psychological Methods, 12, 247-267.

van der Heide, W., Wartna, B. S. J., \& Blom, M. (2004). Tenuitvoerlegging van sancties. In A Th J Eggen \& W. van der Heide (Eds.), Criminaliteit en rechtshandhaving (pp. 173-210). Meppel: Boom Juridische Uitgevers.

Hirschi, T. (1969). Causes of Delinquency. Berkeley: University of California Press.

Hirschi, T., \& Gottfredson, M. (1983). Age and the explanation of crime. The American Journal of Sociology, 89, 552-584.

Junger-Tas, J. (1994). Alternatives to prison sentences: Experiences and developments. New York: Kugler.

Killias, M., Aebi, M., \& Ribeaud, D. (2000). Does community service rehabilitate better than short-term imprisonment?: results of a controlled experiment. The Howard Journal, 39, 40-57.

McAlinden, A. (2005). The use of 'shame' with sexual offenders. British Journal of Criminology, delinquency and deviant social behaviour, 45, 373-394.

Moolenaar, D. E. G. (2005). Uitgaven aan criminaliteit. In A. T. J. Eggen \& W. van der Heide (Eds.), Criminaliteit en Rechtshandhaving 2004. Den Haag: WODC.

Muiluvuori, M. (2001). Recidivism among people sentenced to community service in Finland. Journal of Scandinavian Studies in Criminology and Crime Prevention, 2, 72-82.

Nagin, D. D., Cullen, F. T. \& Jonson, C. L. (2009). Imprisonment and reoffending. Crime and justice, vol. 38 (in press) 
Nieuwbeerta, P., Nagin, D. S., \& Blokland, A. A. J. (2009). Assessing the impact of first-time imprisonment on offenders' subsequent criminal career development: a matched samples comparison. Journal of Quantitative Criminology, 25(3), 227-257.

Nirel, R., Landau, S. F., Sebba, L., \& Sagiv, B. (1997). The effectiveness of service work: an analysis of recidivism. Journal of Quantitative Criminology, 13, 73-92.

Pettit, B., \& Western, B. (2004). Mass imprisonment and the life course: race and class inequality in U.S. incarceration. American Sociological Review, 69, 151-169.

Rosenbaum, P. (2002). Observational Studies (2nd ed.). New York: Springer.

Rosenbaum, P., \& Rubin, D. (1983). The central role for the propensity score in observational studies of causal effects. Biometrika, 70, 41-55.

(1984). Reducing bias in observational studies using subclassification on the propensity score. Journal of the American Statistical Association, 94, 516-524

(1985). 'Constructing a control group using multivariate matched sampling methods that incorporate the propensity score'. The American Statistician, 39, 33-38

Tak, P. J. (2001). Dutch sentencing. In M. Tonry \& R. S. Frase (Eds.), Sentencing and Sanctions in Western Countries. New York: Oxford University Press.

Tonry, M., \& Frase, R. S. (2001). Sentencing and sanctions in Western Countries. New York: Oxford University Press.

Sampson, R. J., \& Laub, J. H. (1995). Crime in the making: Pathways and turning points through life. Cambridge: Harvard University Press.

Schuyt, P. M. (2008). Straffen. In C. P. M. Cleiren \& J. F. Nijboer (Eds.), Strafrecht (pp. 55-150). Deventer: Kluwer.

Shadish, W. R., Clark, M. H., \& Steiner, P. M. (2008). Can nonrandomized experiments yield accurate answers? A randomized experiment comparing random and non-random assignments. Journal of the American Statistical Association, 103(484), 1334-1343.

Sherman, L. W., Gottfredson, D. C., MacKenzie, D. L., Eck, J. E., Reuter, P., \& Bushway, S. (1997). What works, what doesn't, what's promising. Washington DC: Office of Justice Programs.

Spaans, E. C. (1994). Appels en peren: Een onderzoek naar de recidive van dienstverleners en kortgestraften. Arnhem: Gouda Quint.

Spohn, C., \& Holleran, D. (2002). The effect of imprisonment on recidivism rates of felony offenders: a focus on drug offenders. Criminology, 40, 329-358.

Statistics Netherlands. (2008). Misdrijven; opgelegde straffen en maatregelen. http://statline.cbs.nl/ StatWeb/publication/?DM=SLNL\&PA=03727\&D1 $=0-25 \& D 2=0 \& D 30 \& D 4=0 \& D 5=(1-11)-1 \& V W=\mathrm{T}$ (consulted, 08/09/2008)

Sutherland, E. D. (1947). Principles of Criminology. Philadelphia: Lippincott.

Van der Werff, C. (1979). Speciale Preventie. Den Haag (NL): WODC.

Van Noije, L., \& Wittebrood, K. (2008). Sociale veiligheid ontsleuteld: Veronderstelde en werkelijke effecten van veiligheidsbeleid. Den Haag: Sociaal en Cultureel Planbureau.

Villetaz, P., Killias, M. \& Zoder, I. (2006). The effects of custodial vs. non-custodial sentences on re-offending. A systematic review of the state of knowledge. http://www.capbellcollaboration.org/doc-pdf/ Campbell-report-30.09.06.pdf

Wartna, B. S. J. (2009). In de oude fout: Over het meten van recidive en het vaststellen van het succes van strafrechtelijke interventies. Den Haag: WODC.

Windzio, M. (2006). Is there a deterrent effect of pains of imprisonment?: the impact of 'social costs' of first incarceration on the hazard rate of recidivism. Punishment Society, 8, 341-364. 